\title{
Student Indicator
}

National Cancer Institute

\section{Source}

National Cancer Institute. Student Indicator. NCI Thesaurus. Code C147485.

An indication as to whether the subject or associated person is enrolled in school. 